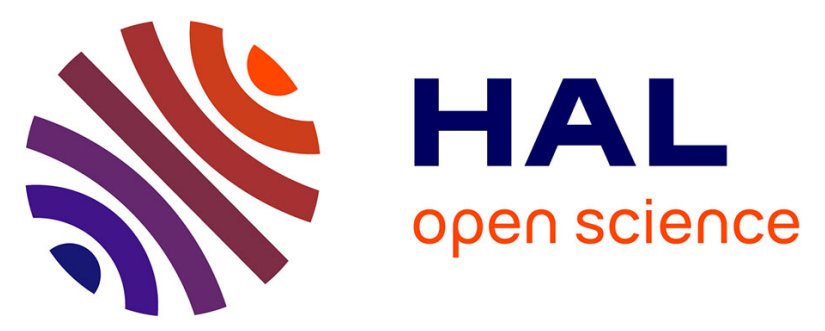

\title{
A new proxy for Cretaceous paleoceanographic and paleoclimatic reconstructions: Coiling direction changes in the planktonic foraminifera Muricohedbergella delrioensis
}

Delphine Desmares, Nemo Crognier, Jérémie Bardin, Marc Testé, Bernard Beaudoin, Danièle Grosheny

\section{To cite this version:}

Delphine Desmares, Nemo Crognier, Jérémie Bardin, Marc Testé, Bernard Beaudoin, et al.. A new proxy for Cretaceous paleoceanographic and paleoclimatic reconstructions: Coiling direction changes in the planktonic foraminifera Muricohedbergella delrioensis. Palaeogeography, Palaeoclimatology, Palaeoecology, 2016, 445, pp.8-17. 10.1016/j.palaeo.2015.12.021 . hal-01259877

\section{HAL Id: hal-01259877 \\ https://hal.sorbonne-universite.fr/hal-01259877}

Submitted on 21 Jan 2016

HAL is a multi-disciplinary open access archive for the deposit and dissemination of scientific research documents, whether they are published or not. The documents may come from teaching and research institutions in France or abroad, or from public or private research centers.
L'archive ouverte pluridisciplinaire HAL, est destinée au dépôt et à la diffusion de documents scientifiques de niveau recherche, publiés ou non, émanant des établissements d'enseignement et de recherche français ou étrangers, des laboratoires publics ou privés. 
A new proxy for Cretaceous paleoceanographic and paleoclimatic reconstructions: Coiling direction changes in the planktonic foraminifera Muricohedbergella delrioensis

Delphine Desmares ${ }^{\mathrm{a},{ }^{*}}$, Nemo Crognier ${ }^{\mathrm{b}}$, Jérémie Bardin ${ }^{\mathrm{a}}$, Marc Testé ${ }^{\mathrm{a}}$, Bernard Beaudoin ${ }^{\mathrm{c}}$, Danièle Grosheny ${ }^{\mathrm{d}}$

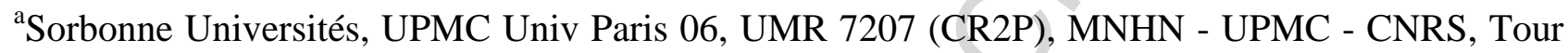
46-56, $5^{\text {ème }}$, case 104, 4, place Jussieu, F-75005, Paris, France

${ }^{\mathrm{b}}$ UMR5150 (LFCR), CNRS-UPPA-TOTAL. Université de Pau et des Pays de l'Adour. BP 1155, 64013 Pau Cedex, France

${ }^{\mathrm{c}}$ Mines-ParisTech, 60 boulevard Saint Michel, 75006 Paris, France

${ }^{\mathrm{d} U M R 7359}$ GéoRessources, Université de Lorraine, boulevard des Aiguillettes, 54506 Vandoeuvrelès-Nancy, France

*delphine.desmares@upmc.fr

\section{ABSTRACT}

Among some modern and recent fossil species of planktonic foraminifera, the proportion of left- to right-coiled shells in a population appears to be temperature-dependent; the relative abundance of each morphotype reflecting ecological preferences. A similar relationship is identified among Muricohedbergella delrioensis (Carsey, 1926) at the Cenomanian-Turonian stage boundary in mid-latitude sites of the Western Interior Seaway, including the Pueblo type section. The increase of sinistral $M$. delrioensis in the assemblage is related to higher $\delta^{18} \mathrm{O}$ carb values and decrease in inner porosity which suggests that changes in the coiling direction in this morphospecies could represent a new proxy for constraining Sea Surface Temperature (SST) variations. As surface dwellers, muricohedbergellids were not 
affected by Oceanic Anoxic Event (OAE2) and provide a continuous paleoclimatic signal throughout the Cenomanian-Turonian boundary interval. Furthermore, genetic evidence obtained from extant foraminifera indicates that shifts of coiling ratios in planktonic foraminifera species can express the signature of distinct genetic types, which are revealed through their opposite coiling directions. Coiling direction could be a genetic trait, implying that cryptic species may occur in the Mesozoic.

\section{Keywords:}

Planktonic foraminifera; Coiling direction; Oceanic Anoxic Event 2; Western Interior Seaway; Sea Surface Temperature

\section{Introduction}

Planktonic foraminifera are globally distributed marine protists. Their distribution, abundance and diversity is strongly linked to surface-water properties, especially sea-surface temperature (SST) gradients. Due to their calcitic shells, these microfossils are frequently preserved in sediments and are widely used for the reconstruction of past oceanic environments. The shells of Neogloboquadrina pachyderma s.l. have been classically used to identify and to constrain Pliocene and Pleistocene glacial and interglacial climates (Ericson, 1959; Bandy, 1960; Bond et al., 1993). Their trochospirally arranged tests exhibit a left- or a right-coiling direction. Paleoceanographers since Ericson (1959) have related the relative abundance of each morphotype to SST; the left-coiled morphotypes being dominant in cold, high northern latitudes whereas their right-coiled counterparts are found in more temperate environments (Bauch et al., 2003; Darling et al., 2006). The temperature-dependent coiling direction among $N$. pachyderma s.l. is not unique; sinistral Globorotalia truncatulinoides Type II and sinistral Globigerina bulloides are also associated with cold temperatures (Boltovskoy, 1973; Darling and Wade, 2008; Ujiie et al., 2010). 
During the Cenomanian-Turonian boundary (CTB) interval, Oceanic Anoxic Event (OAE2) gave rise to profound environmental modifications leading to the disappearance of advanced keeled foraminifera that inhabited deep oceanic waters (Caron and Homewood, 1983). The assemblage spanning the OAE2 is thus mainly composed of globular surface or near-surface dwellers such as Muricohedbergella delrioensis (Carsey, 1926). Oxygen isotope data support the view that $M$. delrioensis inhabited surface or near-surface waters (Price and Hart, 2002; Forster et al., 2007), as also indicated by their paleobiogeographic distribution in open ocean and shallow epeiric sea environments (Hart and Bailey, 1979; Leckie, 1987; Corfield et al., 1990; Huber et al., 1995; Hart, 1999; Bornemann and Norris, 2007). M. delrioensis was an ubiquitous opportunistic morphospecies that occurs abundantly in sediments spanning the late Albian (Moullade, 1966; Leckie et al., 1998; Petrizzo and Huber, 2006; Huber and Leckie, 2011) to the Turonian. Identifying coiling events within the $M$. delrioensis lineage would undoubtedly be of interest because its fossil record is continuous and widespread, especially in shallow-water deposits (Leckie, 1987) and/or at high latitudes (Premoli Silva and Sliter, 1999).

According to Bolli et al. (1971), following a period of random coiling from the Albian to the early Cenomanian, Muricohedbergella would have adopted a preferred dextral coiling direction. Here we present the first high-resolution counts of $M$. delrioensis indicating that there is no preferential coiling mode across the CTB interval. Our work highlights several reversals in coiling direction that could be due to SST changes. To investigate this possibility, our dataset will be compared to two other proxies measured in the same samples: the $\delta^{18} \mathrm{O}_{\text {carb }}$ and the inner porosity of M. delrioensis. Even if it must be interpreted with caution, $\delta^{18} \mathrm{O}_{\text {carb }}$ has been employed as classical indicator of relative seawater temperature (Jenkyns et al., 1994; Jarvis et al., 2011). The inner porosity of $M$. delrioensis is a complementary index for characterising the water mass properties (Fisher, 2003; Fisher et al., 2003). Moreover, with hundreds of publications dedicated to OAE2, the CTB interval is an ideal candidate for testing the possibility of a relationship between coiling direction of M. delrioensis and climatic changes. 


\section{Material and methods}

\subsection{Coiling direction}

In sections from Pueblo and Las Animas (Colorado) and Hot Springs (South Dakota) from the epicontinental Western Interior Seaway (WIS) (Fig. 1), M. delrioensis was collected in diverse lithologies. At Pueblo, 51 closely-spaced samples were analyzed both in limestones and calcareous shales. For the sections of Hot Springs and Las Animas, 40 and 6 shaley levels were examined. In the Contessa Valley of the Umbria-Marche Basin (Fig. 1), planktonic foraminifera were obtained from 21 samples of strongly lithified limestones. Using standard methods, calcareous marls were soaked in a peroxide solution, whereas calcareous limestones were disaggregated using digestion in cold, highly concentrated acetic acid. In both cases, the material was subsequently washed and sieved over a $63 \mu \mathrm{m}$ sieve. When the quantity of residues was sufficient, at least $100 \mathrm{M}$. delrioensis were counted from the $63 \mu \mathrm{m}-1 \mathrm{~mm}$ fraction. Presenting a low trochospiral test with 4,5 to 5,5 globular chambers on the last whorl (Fig. 2), the specimens of M. delrioensis have been observed from the spiral side. Right-coiling refers to those specimens that are coiled in a clockwise direction and left-coiling to those that show an anticlockwise coiling. Counts were made on several samples from the same levels by three authors of this paper and confirm the reproducibility of this method with a maximum 3\% error. Supplementary data (Appendix 1) provides coiling direction data.

\subsection{Degree of correlation between oxygen stable isotopes and coiling direction}

Bulk rock carbonates were analyzed for oxygen and carbon stable isotope composition with a FISON VG OPTIMA mass spectrometer. Carbonate carbon was converted to carbon dioxide with phosphoric acid, using the conventional method. Reproducibility is better than $0.07 \%$ and $0.06 \%$ o 
for $\delta^{18} \mathrm{O}_{\text {carb }}$ and $\delta^{13} \mathrm{C}_{\text {carb }}$ respectively. $\delta^{13} \mathrm{C}_{\text {carb }}$ have been previously published by Desmares et al. (2007).

In order to investigate the degree of correlation between $\delta^{18} \mathrm{O}_{\text {carb }}$ and sinistral morphotype signals, a cross-correlation has been performed using the 'ccf' function from the R package 'stats'. Cross correlations are more appropriate for time series because data are ordered. Then, to test the significance of the cross-correlation, we randomly re-ordered the values of the proportion of the sinistral morphotype and performed a cross-correlation with $\delta^{18} \mathrm{O}_{\text {carb. }}$ This re-ordering procedure was repeated 10000 times. Distributions of cross-correlation values follow a gamma distribution. The best fitting gamma distribution is determined using maximum-likelihood (i.e., function 'fitdistr', $\mathrm{R}$ package 'mass'). A one-tailed test was performed to show that the first cross-correlation (i.e., without re-ordering) was significantly greater than cross-correlations obtained by chance.

\subsection{Porosity analysis procedures}

Hemleben et al. (1989) found that the porosity (percent pore space per unit area) of planktonic foraminifera exhibited changes during ontogeny but stabilized during the late neanic to adult size. In order to be sure of examining the same ontogenetic stage, all the analyzed $M$. delrioensis had 5 to 5,5 chambers in the last whorl and a long diameter measuring between $300 \mu \mathrm{m}$ and $400 \mu \mathrm{m}$. With such dimensions, M. delrioensis are considered to have attained their adult growth stage. Moreover, for the same size range, Fisher (2003) demonstrated that there is no statistical correlation between the $M$. delrioensis diameters and their porosity. Due to the preservation state and extraction methods, the porosity analyses were performed on the calcareous marl levels only. In those levels, the preservation of the tests is excellent (Fig. 2). The samples from the epicontinental WIS are ideal for measuring inner porosity because the planktonic foraminifera accumulated at a maximum water depth of 250_300 m (Sageman and Arthur, 1994). Consequently, they did not suffer dissolution during their descent through the water column. 
Previous studies (Frerichs and Ely, 1978; Fisher, 2003; Fisher et al., 2003) were performed on the last chamber of $M$. delrioensis, because it is larger than the others and more suitable and handier for accessing the inner porosity. However, among the planktonic foraminifera, the terminal stage of ontogeny is often marked by some alterations of the chamber (Hemleben et al., 1989). For this reason, we questioned the representativeness of the last chamber porosity. We tested whether the porosities of the last and penultimate chambers were different or similar in specimens (Supplementary data Appendix 2); we confirmed that there is no difference in porosity between the two last chambers.

Two levels with a highly divergent percentage of sinistral $M$. delrioensis from Hot Springs were investigated. If this difference in the $M$. delrioensis population was caused by SST variations, it should also be expressed by changes test porosity. One contemporaneous sample from Pueblo was analyzed; the other data are derived from the study of Fisher et al. (2003). According to previous works (Frerichs and Ely, 1978; Fisher, 2003), five specimens of adult M. delrioensis per sample would provide adequately consistent values for the mean and variance within any given sample. However, dealing with standard deviation of our preliminary results, we recommend that at least ten specimens per sample be analyzed. In this study, ten to twenty-six specimens per sample have been processed for inner porosity analyses (Supplementary data Appendix 2). In each level, the porosity analyses have been performed on the same quantity of dextral and sinistral specimens.

For each specimen, the last chamber was separated using a needle before being broken into several small fragments. The fragments should not be too large in order to avoid test curvature that would affect the measurements. Each fragment was hand-picked and was transferred onto a scanning electron microscope (SEM) stub with a paintbrush. Using a Hitachi tabletop SEM TM3000, all the fragments have been photographed with x3000 magnification (Fig. 2). This method reveals that the inner porosity of a single chamber is extremely variable; being non existent close to the foramen, porosity increases towards the opposite wall (Fig. 2). The last chamber of $M$. delrioensis remains a very small object $(<200 \mu \mathrm{m})$ and it is impossible to be sure which part of the 
last chamber was photographed. Consequently, we decided to capture images from several fragments of the last chamber of our specimens. As the inner porosity of a single chamber is variable, it is meaningless to calculate a mean from the images. Thus, we systematically took into account the fragment with the maximum porosity.

The images were analyzed using the software JmicroVision 1.2.7.3. The parameters acquired on the photos are: the area $\left(\mu \mathrm{m}^{2}\right)$ of the analyzed surface, the number of pores of this surface and the size parameters of each pore (i.e., its diameter). To compare the concentration of pores between specimens and samples, the analyzed surface has been normalized by a reference area. In order to confront our data with pre-existing information about extant planktonic foraminifera and following the works of Bé (1968), the chosen reference area is $625 \mu \mathrm{m}^{2}$. By setting the gray scale to select only the darkest areas, each pore is filled and assigned to the class "pores" by the operator. If the outline of the pore is not properly drawn, it resets and draws again until a satisfactory result is achieved. The porosity corresponds to the percentage of pore space (i.e., total area of the class "pores") per unit area (i.e., the analyzed surface); pore space being controlled both by the greatest diameter of the pores and their quantity. Repeated image analyses on the same fragment indicate less than $0,5 \%$ of error, the error concerning only the pore area and not the number of pores.

\section{Results and discussion}

\subsection{Coiling direction reversal events through the WIS}

At Pueblo Colorado, the relative percentage of sinistral $M$. delrioensis clearly displays longterm trends punctuated by high frequency coiling reversals (Fig. 3). As this section is the GSSP for the base of the Turonian (Kennedy et al., 2005), the rich archive of previously acquired data (Eicher and Worstell, 1970; Cobban and Scott, 1972; Pratt, 1984; Eicher and Diner, 1985; Leckie, 1985; Pratt, 1985; Kennedy and Cobban, 1991; Leckie et al., 1998; Morel, 1998; Caron et al., 2006; 
Desmares et al., 2007) provides stratigraphic constraints (biostratigraphic markers and the globally recognized positive $\delta^{13} \mathrm{C}$ excursion) to the coiling reversals. Independent marker beds including bentonites (Elder, 1988; Desmares et al., 2007) and the macrofossil biostratigraphy (Elder, 1987; Kennedy and Cobban, 1991) define a chronostratigraphy that allows precise correlations to be made between the WIS sections (Fig. 3). The main events among M. delrioensis are:

(S1) An important rise in the relative percentage of left-coiled M. delrioensis begins in the upper part of the Hartland Shale Member where the proportion of sinistral shells attains more than 40\%. This sinistral M. delrioensis event persists into the lower part of the Sciponoceras gracile ammonite zone before a stepwise decline. Just below the limestone marker bed 63 (Cobban and Scott, 1972), a brief drop subdivides this event in two episodes: S1a and S1b. Temporally, the base of S1b is coincident with the first peak (A) (Pratt and Threlkeld, 1984; Pratt, 1985) of the $\delta^{13} \mathrm{C}$ curve (Fig. 4).

(S2) Of lesser amplitude, S2 occurs in the upper part of the S. gracile ammonite zone and pertains to the general progressive decrease of sinistral forms. The end of S2, at the base of the Neocardioceras juddii ammonite zone, coincides with the onset of the plateau (B) (Pratt and Threlkeld, 1984; Pratt, 1985) of $\delta^{13} \mathrm{C}$ values (Fig. 4).

(D) The lowest abundances of left-coiled morphotypes $(<10 \%)$ are recorded close to the CTB. In detail, three successive lows are observed: (a) encompassing the bentonite B in the $N$. juddii ammonite zone, (b) just below the CTB and (c) just after the CTB in the Watinoceras devonense ammonite zone. These lows are coeval with the $\delta^{13} \mathrm{C}$ plateau of values (B).

At Hot Springs (South Dakota), located $600 \mathrm{~km}$ to the north, long-term and high frequency coiling direction changes are remarkably synchronous with those defined in Pueblo (Fig. 3). In the S. gracile ammonite zone, a maximum of $30 \%$ of sinistral $M$. delrioensis is recorded just above bentonite A, which corresponds to the uppermost part of S1b before a decrease higher in the section. Due to the poor outcrop exposures, the interval encompassing S1a was not sampled at Hot Springs, 
but S1a has been clearly identified in several other sections such as in Las Animas (Colorado) located $130 \mathrm{~km}$ east of Pueblo (Fig. 3). In the calcareous marls close to the CTB at Hot Springs, left-coiled morphotypes show three successive lows that correspond to the D ('dextral') event. Based on the ammonite biostratigraphic scheme (Elder, 1987), the increase of sinistral specimens between $\mathrm{Db}$ and $\mathrm{Dc}$ is a lateral equivalent of the limestone marker bed 86 that marks the position of the CTB. Similarities between these two distant sections indicate that the changes in the percentage of the sinistral morphotypes are the expression of environmental modifications at least at the scale of the WIS.

\subsection{Linking oxygen isotope events and coiling direction changes among M. delrioensis}

The effects of diagenesis on oxygen isotopic composition of bulk pelagic carbonates $\left(\delta^{18} \mathrm{O}_{\text {carb }}\right)$ are often debated. Nevertheless, trends in the $\delta^{18} \mathrm{O}_{\text {carb }}$ have been interpreted to provide a proxy for identifying relative changes in the SSTs (Jenkyns et al., 1994; Jarvis et al., 2011). For example, in the WIS (Fig. 3), it has been argued that the anomalously light $\delta^{18} \mathrm{O}_{\text {carb }}$ is likely due to influx of freshwater into the seaway and not by a major diagenetic effect (Keller and Pardo, 2004). But other authors such as Pratt et al. (1993) concluded that the light $\delta^{18} \mathrm{O}_{\text {carb }}$ values are diagenetic at the Pueblo section but that the relative changes (more enriched and more depleted trends) are likely robust. Moreover, the isotopic profiles of Pueblo and Hot Springs resemble each other closely despite the different types of sediment (alternating limestones-marls $v s$ calcareous marls) and are perfectly synchronous and comparable to the $\delta^{18} \mathrm{O}_{\text {carb }}$ of other European types sections (Pearce et al., 2009). These $\delta^{18} \mathrm{O}_{\text {carb }}$ profiles record long-term fluctuations; values begin to increase gradually from the Metiococeras mosbyense ammonite zone to the base of the S. gracile ammonite zone before a return to even lower values in the N. juddii ammonite zone and the CTB. At Pueblo, the $\delta^{18} \mathrm{O}_{\text {carb }}$ positive excursion values, culminating below bentonite A within the $S$. gracile ammonite zone, is a well recognized feature in the midlatitudes interpreted as an episode of short-lived cooling 
(Pearce et al., 2009; Jarvis et al., 2011). These similarities reinforce the argument for the retention of a primary climate signal in the $\delta^{18} \mathrm{O}_{\text {carb }}$ data.

If the proportion of sinistral/dextral forms of Cretaceous foraminifera were related to temperature, as has been observed in some extant forms, then we would expect a correlation between $\delta^{18} \mathrm{O}$ in carbonate and the percentage of sinistral forms. For Bridge Creek Limestone Member, from the base of the S. gracile ammonite zone up to the bentonite $\mathrm{D}$, the $\delta^{18} \mathrm{O}_{\text {carb }}$ and the percentages of sinistral M. delrioensis present parallel long-term trends (Fig. 3); high frequency variations generally being in the same direction. This is supported by a statistically highly significant correlation between the two data sets. At Pueblo, the first cross-correlation performed on the entire section (i.e., including upper part of Hartland Shale) was not significant. When we repeated the procedure on the Bridge Creek Limestone Member only, the raw correlation is greater than the 0.99 quantile (Fig. 5A). Consequently, the correlation between $\delta^{18} \mathrm{O}_{\text {carb }}$ and proportion of sinistral forms for the Bridge Creek Limestone Member is highly significant $(\alpha=0.01)$. This discrepancy could be explained by the subsaline, restricted environment of the Hartland Shale that would have lowered the $\delta^{18} \mathrm{O}_{\text {carb }}$ (Sageman, 1985; Keller et al., 2004; Arthur and Sageman, 2005). In contrast, a more normal marine environnement prevailed in the Bridge Creek Limestone. Moreover, Keller et al. (2004) argued that the magnitude of salinity variations during the deposit of the Hartland Shale was twice as much as during the sea-level transgression of the Bridge Creek Limestone. Indeed, the Hartland Shale was a time of a more restricted seaway not well connected to the Tethyan water masses (Arthur and Sageman, 2005). These conditions would have impacted the $\delta^{18} \mathrm{O}_{\text {carb }}$ that cannot be interpreted only in terms of temperature variation in the Hartland Shale.

For the Bridge Creek Limestone Member at Hot Springs (Fig. 5B), the raw correlation is greater than the 0.99 quantile, indicating that the correlation between $\delta^{18} \mathrm{O}_{\text {carb }}$ and the abundance of sinistral M. delrioensis is highly significant $(\alpha=0.01)$. The concordant evolution of these two signals indicates that they could have been influenced by the same environmental modifications.

In the $S$. gracile ammonite zone, the high proportion of sinistral shells ( $\mathrm{S} 1 \mathrm{~b})$, coincident with 
high $\delta^{18} \mathrm{O}_{\text {carb }}$ values, could be a response to a decline in SST (Fig. 3). This cooling episode is particularly well expressed in southern England and France where the positive $\delta^{18} \mathrm{O}$ excursion (Jarvis et al., 2011) within the mid-Metoicoceras geslinianum ammonite zone (S. gracile equivalent) is recognizable elsewhere and coincide with the Plenus Cold Event, a temporary influx of Boreal fauna throughout Europe (Jefferies, 1962; Gale and Christensen, 1996). Close to the CTB, the lowest percentages of left-coiled forms and values of $\delta^{18} \mathrm{O}_{\text {carb }}$ record a thermal maximum (Fig. 3). Falling $\delta^{18} \mathrm{O}$ through the Upper Cenomanian, with a minimum in the lowest Turonian is interpreted to be a period of maximum global SSTs during an Early Turonian climatic optimum. This event is globally recorded from Europe (Jenkyns et al., 1994; Jarvis et al., 2011) to the Southern Hemisphere (Clarke and Jenkyns, 1999); $\delta^{18} \mathrm{O}$ data on planktonic foraminifera (Huber et al., 2002; Forster et al., 2007) from low latitude sites of the western Atlantic also support this interpretation.

These main trends are modulated by reversals of lesser amplitude with high frequency changes between fewer sinistral forms/low $\delta^{18} \mathrm{O}_{\text {carb }}$ and more sinistral forms/less negative $\delta^{18} \mathrm{O}_{\text {carb. }}$ The parallelism between the percentages of sinistral forms and the $\delta^{18} \mathrm{O}_{\text {carb }}$ strengthens the robustness of the geochemical data sets. The abundance of sinistral morphotypes is independent of diagenesis, which affects the dextral and sinistral shells with the same intensity, and it supports the interpretation of the $\delta^{18} \mathrm{O}_{\text {carb }}$ variations which are often cast aside because of their supposed diagenetic overprint.

\subsection{Ecophenotypes or genotypes?}

If coiling direction changes among $M$. delrioensis are primarily dependant upon SSTs, we conclude that dextral and sinistral morphotypes have distinct ecological preferences, which could be due to ecophenotypy. Recent advances in planktonic foraminiferal molecular genetic analysis provide new insights concerning their diversity which, in the past, has been underestimated (De 
Vargas et al., 1999; Bauch et al., 2003; Darling et al., 2006; Darling and Wade, 2008; Morard et al., 2009; Ujiie et al., 2010); morphospecies as previously understood, being in fact composed of several cryptic species. Among the extant $N$. pachyderma s.l., the dextral forms now named Neogloboquadrina incompta and the left-coiled N. pachyderma, are in reality different species with distinct ecologies and biogeographic distributions (Darling et al., 2006). However, genetic studies reveal the presence of extensive diversity. To date, seven and two Small Subunit ribosomal RNA genotypes, with their own provincial ranges, are reported for $N$. pachyderma and for $N$. incompta, respectively (Darling and Wade, 2008). Dealing with their environmental preferences, coiling direction reversals among $N$. pachyderma s.l. in the fossil record could be interpreted in terms of increasing dominance of one coiling type (one species) in a mixed assemblage comprising at least two species. Focussing on cryptic species is essential because the coiling differences among $N$. pachyderma s.l. are mainly related to the SST variations. Although lack of DNA in fossil foraminiferal shells precludes genetic investigations, the recognition of potential fossil cryptic species would greatly enhance the role of foraminifera as indicators of past climates.

By analog with $N$. pachyderma s.1., the two morphotypes of $M$. delrioensis could be distinct species with their own ecologies and biogeographic ranges. Considering current knowledge about extant foraminifera, the coiling direction alone is not a sufficient criterion for splitting the opposite morphotypes into two species. As an example, G. truncatulinoides Type II displays both left- and right-coiled forms. But, this species belongs to a young lineage (<170 k.y.). Due to this short time span, populations of G. truncatulinoides Type II may have just remained dimorphic for coiling direction (Ujiie et al., 2010). In contrast, the two forms of $N$. pachyderma s.l. have co-existed since the late Miocene (Darling et al., 2006). Since their emergence, the period was long enough for the two morphotypes to diverge genetically. M. delrioensis which appeared during the late Albian, (Moullade, 1966; Petrizzo and Huber, 2006; Huber and Leckie, 2011) more than 6 million years before the CTB, had the potential to evolve into at least two distinct genetic types.

In any case, whether temperature-depend coiling is linked to ecophenotypy or highlights 
different cryptic species, it is a valuable indicator. It is not certain that this enigma will be elucidated in the future. Morphometric or isotopic analysis could provide more evidences. Cryptic species can present morphological differences that have been often previously unnoticed (Kucera and Darling, 2002). As an example, N. pachyderma and N. incompta present distinct phenotypes. However, in other cryptic species such differences are recondite. Dextral and sinistral M. delrioensis seem to be morphologically very similar (Fig. 2). With morphometric analysis, the challenge ahead is to test if useful criteria for the discrimination of the dextral and sinistral $M$. delrioensis exist. If the genetic diversity can be translated into morphological features, the genetic types will no longer need to have the label "cryptic" and it will become possible to differentiate at least some of them in the fossil record. However, it may be a wishful thinking because, contrariwise, a recent study (André et al., 2013) has demonstrated the lack of genetic differentiation within the morphologically diverse plexus of the planktonic foraminifer Globigerinoides sacculifer. Considering its old age (early Miocene), the genetic homogeneity within the morphospecies was unexpected (André et al., 2013).

During Holocene, a systematic $\delta^{18} \mathrm{O}$ offset of about $0,5 \%$ is observed between $N$. pachyderma and N. incompta (Bauch et al., 2003). Preliminary isotopic investigations on wellpreserved and empty $M$. delrioensis from the cenomanian stratotypic area (close to Le Mans, France) revealed a similar relationship with a systematic difference of $0,5 \%$ between the dextral and the sinistral morphotypes (when the assemblage contain more than $10 \%$ of sinistral forms). Such an offset may represent a genotype-specific vital effect that could highlight two distinct species among the $M$. delrioensis morphotypes. If dextral and sinistral M. delrioensis are clearly adapted to water masses with different properties, it remains to determine if the species-depend $\delta^{18} \mathrm{O}$ offset represents annual, seasonal or water-depth hydrological differences, a vital effect or a combination of them.

\subsection{Inner test porosity of $\mathrm{M}$. delrioensis}


Two works on extant planktonic foraminifera (De Vargas et al., 1999; Morard et al., 2009) indicate that genotypes can be distinguished by differences in the porosity of the inner test. Student's t-tests performed on the porosity measurements of sinistral and dextral M. delrioensis, both on the pore concentration and on the mean diameters do not yield significant differences between the two morphotypes (Figs. 6 and 7). If the porosity of the dextral and sinistral forms from the Pueblo and Hot Springs sections does not show significant differences, it does provide information concerning the characteristics of the water mass.

In modern oceans, a correlation between planktonic foraminiferal test porosity and water mass characteristics such as temperature and salinity has been observed. As an example, with the pioneering study of Bé (1968), shell porosity in extant planktonic foraminifera seems to be relatively uniform for those lineages inhabiting the same latitudinal belt. Controlled by the water mass temperature and/or by the salinity, test porosity could be used as an indicator of climate. Illustrating the potential of such an investigation in the fossil record, previous analyses on $M$. delrioensis reported a latitudinal dependence of test porosity through the WIS (Fisher et al., 2003).

Because oxygen isotopes, although potentially providing valuable information on changes in seawater temperature and salinity, can be obliterated by diagenetic alteration, test porosity of $M$. delrioensis is an additional and complementary indicator that could strengthen geochemical interpretations.

The laboratory experiments by Bijma et al. (1990) demonstrated that greater test porosity is primarily controlled by higher temperature and secondarily by lower salinity. But the responses to salinity or temperature variations are different. In the case of a rise in temperature, both the size and the density of pores increase. In contrast, a decrease in salinity has only a strong influence on the density of pores; the size of the pores being similar under low and high salinities (Bijma et al., 1990)

Our data agree with the parallel variations of the percentage of sinistral forms and of the $\delta^{18} \mathrm{O}_{\text {carb }}$ (Fig. 3). During S1b (S. gracile ammonite zone), the average inner porosity of right-coiled 
M. delrioensis is low with $6 \%$ below bentonite A at Pueblo and $7 \%$ above bentonite A at Hot Springs. Just after the deposition of bentonite B ( $N$. juddii ammonite zone), the average porosity of dextral M. delrioensis increases to $17 \%$ (Fisher et al., 2003) at Pueblo and to 14\% at Hot Springs, on the same time line. At Hot Springs, the main porosity between the two samples is statistically different (Krustal-Wallis test, $\mathrm{p}<0.0001)$.

Almost of the same magnitude in the two sections, the porosity difference between S1b and Da cannot be explained by a difference in salinity alone. The porosity parameters indicate that this change is controlled both by a 1.4 factor increase in the size of the pores (at Hot Springs average diameters of the pores are respectively of $1.6 \mu \mathrm{m}$ in S1b and $2.2 \mu \mathrm{m}$ in Da) and by a rise in the pore density (at Hot Springs average pore densities are respectively 21 pores per $625 \mu \mathrm{m}^{2}$ in S1b and 26 pores per $625 \mu \mathrm{m}^{2}$ in Da). Following the works of Bijma et al. (1990), such enlargement of the pores is likely due to a temperature increase. With our current knowledge, laboratory experiments are too few to propose a transfer function linking the porosity differential to a quantified variation in temperature. Nevertheless, dealing with the present mean porosity values (Bé, 1968), the difference between S1b and Da at Pueblo and Hot Springs could be of the same order of magnitude as the difference between extant temperate and subtropical to tropical SSTs. Such an estimation is in agreement with the SST changes evaluated by Sinninghe Damsté et al. (2010) and Jarvis et al. (2011) for other mid-latitude sites of the Northern Hemisphere.

\section{Paleoceanographic and paleoclimatic implications}

In linking $\delta^{18} \mathrm{O}_{\text {carb }}$ and test porosity analyses, coiling-direction reversals among $M$. delrioensis are likely to be due to SST variations. In the WIS, the first cooling event (S1a) is recorded below the limestone marker bed 63 in the Hartland Shale (Fig. 3). Even if $\delta^{18} \mathrm{O}_{\text {carb }}$ was lowered due to subsaline conditions, such a trend is noticeable at Pueblo with the slight increase of the $\delta^{18} \mathrm{O}_{\text {carb }}$ values. This tendency is clearly expressed by the $\delta^{18} \mathrm{O}$ variations of European sections 
(i.e., Eastbourne in southern England or Gröbern in northern Germany) at the same stratigraphic interval (Paul et al., 1999; Voigt et al., 2006; Jarvis et al., 2011). If according to the estimations of Jarvis et al. (2011) the SST during S1a seems to be a little warmer than during S1b, SST are nevertheless cold enough for the ecological preferences of the sinistral M. delrioensis. Between S1a and $\mathrm{S} 1 \mathrm{~b}$, at the beginning of the $S$. gracile ammonite zone, a sharp and short drop in the percentage of sinistral M. delrioensis occurs (Fig. 3). Based on $\mathrm{CO}_{2}$ proxies (terrestrial leaf stomata and $\Delta^{13} \mathrm{C}$ ), this drop could be linked to a major $\mathrm{CO}_{2}$ pulse attributed to the intense volcanic activity accompanying the initial emplacement of the Caribbean large igneous plateau (Barclay et al., 2010; Jarvis et al., 2011). After this brief SST warming, the percentage of sinistral M. delrioensis dramatically increases within the mid- S. gracile ammonite zone (S1b) highlighting a cooling event (Fig. 3). Contemporaneous with the Plenus Cold Event, this cooling episode is attributed by Jarvis et al. (2011) to the decrease of the $\mathrm{pCO}_{2}$ due to carbon sequestration by marine organic productivity and preservation, and increased silicate weathering. Rapid decrease of the percentage of sinistral $M$. delrioensis began in the upper part of the $S$. gracile ammonite zone up to the CTB (Fig. 3). This renewed increase in SST suggests that a continuing volcanogenic $\mathrm{CO}_{2}$ flux could have overridden the drawdown effects (Jarvis et al., 2011).

Other paleothermometers, such as the $\mathrm{TEX}_{86}$, indicate very high SSTs close to the CTB in the proto-North Atlantic (Sinninghe Damsté et al., 2010). Coeval with the plateau of $\delta^{13} \mathrm{C}$ values (B), this warm period spans the same interval as the D-event. Below the CTB, Sinninghe Damsté et al. (2010) identified a cooling event $\left(>5^{\circ} \mathrm{C}\right)$ coincident with the $\delta^{13} \mathrm{C}$ initial peak (A) and contemporaneous S1b event. These events not only affected mid-latitude sites; SST variations have been recorded in the equatorial Atlantic (Forster et al., 2007), suggesting that they may have been driven by global climatic changes. The coiling change events among the $M$. delrioensis populations should thus be identifiable in other paleogeographic domains. In the Contessa Valley (Fig. 4), the M. delrioensis populations are dramatically different on either side of the Bonarelli Level, an organic rich horizon devoid of carbonates that interrupts the Scaglia Bianca Formation. In the metre 
below, while the $\delta^{13} \mathrm{C}$ excursion had not yet started, sinistral $M$. delrioensis are abundant and associated with common rotaliporids. This interval can be assigned to S1a. Coiling direction is in this case a useful stratigraphic marker. As already suggested by Tsikos et al. (2004), it indicates that the base of the Bonarelli Level is coeval with the cooling phase S1b. Two and a half metres above the Bonarelli Level, just after the main isotopic $\delta^{13} \mathrm{C}$ excursion (B), the low abundance of left-coiled M. delrioensis (Dc) indicates as elsewhere, warm SSTs for the lower Turonian of the Tethyan Realm.

\section{Conclusions}

Variation in coiling direction of $M$. delrioensis through the CTB interval overwhelmingly reflects a significant correlation with the $\delta^{18} \mathrm{O}_{\text {carb}}$, and therefore offers a good proxy for SST changes. Thus, in accordance with previously published studies, coiling shifts allow the recognition of the main climatic changes that occurred at the CTB interval.

Micropaleontologists have generally lost interest in $M$. delrioensis because this small morphospecies has a long stratigraphic range and a wide distribution and was therefore considered to be of little biostratigraphic or paleoenvironmental importance. However, acquiring coiling direction data on $M$. delrioensis is a simple, rapid, reproducible and low cost method that can be applied continuously from proximal to open marine sedimentary facies spanning the late Albian to Turonian. Because the relative abundance of dextral and sinistral forms is likely temperaturedependant, these data are essential for constraining paleoceanographic and paleoclimatic changes during the mid-Cretaceous period. Moreover, with a lack of genetic material a considerable amount of planktonic foraminifera paleobiodiversity has been obviously missed or attributed to ecophenotypy by morphological taxonomies. As in the case of $M$. delrioensis, coiling direction changes could be the first evidence of the existence of of cryptic fossil species. Despite these potentials, coiling direction of Mesozoic planktonic foraminifera remains poorly documented (Bolli, 
1950; Bolli et al., 1971; Caron, 1981; Malgren, 1989; Norris and Nishi, 2001; Desmares et al., 2008). In view of the contribution of such an investigation to climate reconstruction, this method has to be applied to other species with trochospirally arranged chambers; especially on the muricohedbergellid and hedbergellid lineages which are widespread and abundant throughout the Cretaceous and from which emerged the probable ancestor of the Paleocene planktonic foraminifera.

\section{Acknowledgements}

We thank Marco Menichetti and Rodolfo Coccioni for their help while sampling at Gubbio; Alexandre Lethiers for the drawings; Jean-Baptiste Girault and Désiré Zégbé Kouamé for their help in sample processing; Bilal Haq and Mark Leckie for their helpful comments and Martin Pickford for improving the English. 


\section{References}

André, A., Weiner, A., Quillévéré, F., Aurahs, R., Morard, R., Douady, C.J., de GaridelThoron, T., Escarguel, G., de Vargas, C., Kucera, M., 2013. The cryptic and the apparent reversed: lack of genetic differentiation within the morphologically diverse plexus of the planktonic foraminifer Globigerinoides sacculifer. Paleobiology 39, 21-39.

Arthur, M.A., Sageman, B.B., 2005. Sea Level Control on Source Rock Development: Perspectives from the Holocene Black Sea, the mid-Cretaceous Western Interior Basin of North America, and the Late Devonian Appalachian Basin, in: Harris, N.B., Pradier, B. (Eds.), The Deposition of Organic Carbon-rich Sediments: Models, Mechanisms and Consequences. SEPM Special Publication, pp. 35-59.

Bandy, O.L., 1960. The geologic significance of coiling ratios in the foraminifer Globigerina pachyderma. Journal of Paleontology 34, 671-681.

Barclay, R.S., McElwain, J.C., Sageman, B.B., 2010. Carbon sequestration activated by a volcanic CO2 pulse during Ocean Anoxic Event 2. Nature Geosciences 3, 205-208.

Bauch, D., Darling, K., Simstich, J., Bauch, H.A., Erlenkeuser, H., Kroon, D., 2003. Palaeoceanographic implications of genetic variation in living North Atlantic Neogloboquadrina pachyderma. Nature 424, 299-302.

Bé, A.W., 1968. Shell Porosity of Recent Planktonic Foraminifera as a Climatic Index. Science 161, 881-161.

Bijma, J., Faber, W.W., Hemleben, C., 1990. Temperature and salinity limits for growth and survival of some planktonic foraminifers in laboratory cultures. Journal of Foraminiferal Research 20, 95-116.

Bolli, H., 1950. The direction of coiling in the evolution of some Globorotaliidae. Contributions from the Cushman Foundation for Foraminiferal Research 1, 82-89.

Bolli, H.M., Funnell, B.M., Riedel, W.R., 1971. The direction of coiling in planktonic 
foraminifera, The micropalaeontology of oceans. Cambridge University press, Cambridge, pp. 639647.

Boltovskoy, E., 1973. Note on the determination of absolute surface water paleotemperature by means of the foraminifer Globigerina bulloides D'ORBIGNY Paläontologische Zeitschrift 47, $152-155$.

Bond, G.C., Broecker, W., Johnsen, S., Mcmanus, J., 1993. Correlations between climate records from North Atlantic sediments and Greenland ice. Nature 365, 143-147.

Bornemann, A., Norris, R.D., 2007. Size-related stable isotope changes in Late Cretaceous planktic foraminifera: implications for paleoecology and photosymbiosis. Marine Micropaleontology 65, 32-42.

Caron, M., 1981. Un nouveau genre de foraminifère planctonique du Crétacé : Falsotruncana nov. gen. Eclogae Geologicae Helvetiae 74, 65-73.

Caron, M., Dall'Agnolo, S., Accarie, H., Barrera, E., Kauffman, E.G., Amedro, F., Robaszynski, F., 2006. High-resolution stratigraphy of the Cenomanian/Turonian boundary interval at Pueblo (USA) and Wadi Bahloul (Tunisia): stable isotope and bio-events correlation. Geobios 39, $171-200$

Caron, M., Homewood, P., 1983. Evolution of Early Planktic Foraminifers. Marine Micropaleontology 7, 453-462.

Clarke, L.J., Jenkyns, H.C., 1999. New oxygen isotope evidence for long-term Cretaceous climatic change in the Southern Hemisphere. Geology 27, 699-702.

Cobban, W.A., Scott, G.R., 1972. Stratigraphy and Ammonite Fauna of the Graneros Shale and Greenhorn Limestone Near Pueblo, Colorado. Geological Survey Professional Paper 645, 108.

Corfield, R.M., Hall, M.A., Brasier, M.D., 1990. Stable Isotope evidence for foraminiferal habitats during the development of the Cenomanian/Turonian oceanic anoxic event. GEOLOGY 18, 175-178.

Darling, K., Kucera, M., Kroon, D., Wade, C.M., 2006. A resolution for the coiling direction 
paradox in Neogloboquadrina pachyderma. Paleoceanography 21, PA2011.

Darling, K.F., Wade, C.M., 2008. The genetic diversity of planktonic foraminifera and the global distribution of ribosomal RNA genotypes. Marine Micropaleontology 67, 216-238.

De Vargas, C., Norris, R., Zaninetti, L., Gibb, S.W., Pawlowski, J., 1999. Molecular evidence of cryptic speciation in planktonic foraminifers and their relation to oceanic provinces. Proceedings of the National Academy of Sciences 96, 2864-2868.

Desmares, D., Grosheny, D., Beaudoin, B., 2008. Ontogeny and phylogeny of Upper Cenomanian rotaliporids (Foraminifera). Marine Micropaleontology 69, 91-105.

Desmares, D., Grosheny, D., Beaudoin, B., Gardin, S., Gauthier-Lafaye, F., 2007. High resolution stratigraphic record constrained by volcanic ashes layers at the Cenomanian-Turonian boundary in the Western Interior Basin, USA. Cretaceous Research 28, 561-582.

Eicher, D.L., Diner, R., 1985. Foraminifera as indicators of water mass in the Cretaceous Greenhorn Sea, Western Interior, in: Pratt, L.M., Kauffman, E.G., Zelt, F.B. (Eds.), Fine-grained deposits of cyclic sedimentary processes. SEPM Field Trip Guidebook, pp. 60-71.

Eicher, D.L., Worstell, P., 1970. Cenomanian and Turonian foraminifera from the Great Plains, United States. Micropaleontology 16, 269-324.

Elder, W.P., 1987. Cenomanian-Turonian (Cretaceous) stage boundary extinctions in the Western Interior of the United States. Ph.D. Thesis, University of Colorado, p. 621.

Elder, W.P., 1988. Geometry of Upper Cretaceous bentonite beds : Implications about volcanic source areas and paleowind patterns, Western Interior, United States. Geology 16, 835-838.

Ericson, D.B., 1959. Coiling Direction of Globigerina pachyderma as a Climatic Index. Science 130, 219-220.

Fisher, C., 2003. Planktic foraminiferal porosity: a water mass proxy for latest Cenomanian paleoceanography, Greenhorn Sea, Western Interior USA and Canada. Cretaceous Research 24, 633-651.

Fisher, C.G., Sageman, B.B., Asure, S.E., Acker, B., Mahar, Z., 2003. Planktic Foraminiferal 
Porosity Analysis as a tool for Paleoceanographic Reconstruction, Mid-Cretaceous Western Interior Sea. Palaios 18, 34-46.

Forster, A., Schouten, S., Moriya, K., Wilson, P., 2007. Tropical warming and intermittent cooling during the Cenomanian/Turonian anoxic event 2: Sea surface temperature records from the equatorial Atlantic. Paleoceanography 22.

Frerichs, W.E., Ely, R., 1978. Test porosity as a paleoenvironmental tool in the late Cretaceous of the Western Interior. Contribution to Geology, Univ. of Wyoming 16, 89-93.

Gale, A.S., Christensen, W.K., 1996. Occurence of the belemnite Actinocamax plenus in the Cenomanian of SE France and its signifiance. Bulletin of the Geological Society of Denmark 43, 68-76.

Hart, M.B., 1999. The evolution and biodiversity of Cretaceous Planktonic Foraminiferida. Geobios 32, 247-255.

Hart, M.B., Bailey, H.W., 1979. The distribution of planktonic foraminiferida in the midCretaceous of NW Europe, in: Wiedman, J. (Ed.), Aspekte der Kreide Europas. Intetnational Union of Geological Sciences, pp. 527-542.

Hemleben, C., Spindler, M., Anderson, O.R., 1989. Modern Planktonic Foraminifera. Springer-Verlag.

Huber, B.T., Hodell, D.A., Hamilton, C.P., 1995. Middle-Late Cretaceous climate of the southern high latitudes: Stable isotopic evidence for minimal equator-to-pole thermal gradients. GSA Bulletin 107, 1164-1191.

Huber, B.T., Leckie, R.M., 2011. Planktic foraminiferal species turnover across deep-sea Aptian/Albian boundary sections. Journal of Foraminiferal Research 41, 53-95.

Huber, B.T., Norris, R.D., MacLeod, K.G., 2002. Deep- sea paleotemperature record of extreme warmth during the Cretaceous. Geology 30, 123-126.

Jarvis, I., Lignum, J.S., Gröcke, D.R., Jenkyns, H.C., Pearce, M.A., 2011. Black shale deposition, atmospheric $\mathrm{CO} 2$ drawdown, and cooling during the Cenomanian- Turonian Oceanic 
Anoxic Event. Paleoceanography 26.

Jefferies, R.P.S., 1962. The palaeoecology of the Actinocamax plenus subzone (lowest Turonian) in the Anglo- Paris Basin. Palaeontology 4, 609-647.

Jenkyns, H.C., Gale, A.S., Corfield, R.M., 1994. Carbon- and oxygen-isotope stratigraphy of the English Chalk and Italian Scaglia and its palaeoclimatic significance. Geological magazine 131, $1-34$.

Kauffman, E.G., 1984. Paleobiogeography and evolutionary response dynamic in the cretaceous Western Interior Seaway of North America, in: Westermann, G.E.G. (Ed.), JurassicCretaceous Biochronology and Paleogeography of North America. Geological Association of Canada Special Paper, pp. 273-306.

Keller, G., Berner, Z., Adatte, T., Stueben, D., 2004. Cenomanian-turonian and 13C, and 180, sea level and salinity variations at Pueblo, Colorado. Palaeogeography, Palaeoclimatology, Palaeoecology 211, 19-43.

Keller, G., Pardo, A., 2004. Age and paleoenvironment of the Cenomanian-Turonian global stratotype section and point at Pueblo, Colorado. Marine Micropaleontology 51, 95-128.

Kennedy, W.J., Cobban, W.A., 1991. Stratigraphy and interregional correlation of the Cenomanian-Turonian transition in the Western Interior of the United States near Pueblo, Colorado, a potential boundary stratotype for the base of the Turonian Stage. Newsletters on Stratigraphy 24, 1-33.

Kennedy, W.J., Walaszczyk, I., Cobban, W.A., 2005. The Global Boundary Stratotype Section and Point for the base of the Turonian Stage of the Cretaceous: Pueblo, Colorado, U.S.A. Episodes 28, 93-104.

Kucera, M., Darling, K.F., 2002. Cryptic species of planktonic foraminifera: their effect on palaeoceanographic reconstructions. Philosophical Transactions: Mathematical, Physical and Engineering Sciences 360, 695-718.

Leckie, R.M., 1985. Foraminifera of the Cenomanian-Turonian boundary interval, 
Greenhorn Formation, Rock Canyon Anticline, Pueblo, Colorado, in: Pratt, L.M., Kauffman, E.G., Zelt, F.B. (Eds.), Fine-grained deposits of cyclic sedimentary processes. SEPM Field Trip Guidebook, pp. 139-149.

Leckie, R.M., 1987. Paleoecology of mid-Cretaceous planktonic foraminifera : A comparison of open ocean and Epicontinental Sea assemblages. Micropaleontology 33, 164-176.

Leckie, R.M., Yuretich, R.F., West, O.L.O., Finkelstein, D., Schmidt, M.G., 1998. Paleoceanography of the southwestern Western Interior Sea during the time of the CenomanianTuronian boundary (Late Cretaceous), in: Arthur, M.A., Dean, W.E. (Eds.), Stratigraphy and paleoenvironments of the Cretaceous Western Interior seaway. SEPM Concepts in Sedimentology and Paleontology, pp. 101-126.

Malgren, B.A., 1989. Coiling pattern in terminal Cretaceous planktonic foraminifera. Journal of Foraminiferal Research 19, 311-323.

Morard, R., Quillévéré, F., Escarguel, G., Ujiie, Y., De Garidel-Thoron, T., Norris, R.D., De Vargas, C., 2009. Morphological recognition of cryptic species in the planktonic foraminifer Orbulina universa. Marine Micropaleontology 71, 148-165.

Morel, L., 1998. Stratigraphie à Haute Résolution du passage Cénomanien-Turonien. Université Pierre et Marie Curie, Paris VI, p. 224.

Moullade, M., 1966. Etude stratigraphique et micropaleontologique du Crétacé inférieur de la “fosse vocontienne'. Documents des Laboratoires de Géologie de la Faculté des Sciences de Lyon 15, 1-369.

Norris, R.D., Nishi, H., 2001. Evolutionary trends in coiling of tropical Paleogene planktic foraminifera. Paleobiology 27, 327-347.

Paul, C.R.C., Lamolda, M.A., Mitchell, S.F., Vaziri, M.R., Gorostidi, A., Marshall, J.D., 1999. The Cenomanian - Turonian boundary at Eastbourne (Sussex, UK) : a proposed European reference section. Palaeogeography, Palaeoclimatology, Palaeoecology 150, 83-121.

Pearce, M., Jarvis, I., Tocher, B.A., 2009. The Cenomanian-Turonian boundary event, 
OAE2 and palaeoenvironmental change in epicontinental seas: New insights from the dinocyst and geochemical records. Palaeogeography, Palaeoclimatology, Palaeoecology 280, 207-234.

Petrizzo, M.R., Huber, B.T., 2006. Biostratigraphy and taxonomy of Late Albian planktonic foraminifera from ODP Leg 171B (Western North Atlantic Ocean). Journal of Foraminiferal Research 36, 166-190.

Pratt, L.M., 1984. Influence of paleoenvironmental factors on preservation of organic matter in middle Cretaceous Greenhorn Formation, Pueblo, Colorado. The American Association of Petroleum Geologists Bulletin 68, 1146-1159.

Pratt, L.M., 1985. Isotopic studies of organic matter and carbonates in rocks of the Greenhorn Marine cycle, in: Pratt, L.M., Kauffman, E.G., Zelt, F.B. (Eds.), Fine-grained deposits of cyclic sedimentary processes. SEPM Field Trip Guidebook, pp. 38-48.

Pratt, L.M., Arthur, M.A., Dean, W.E., Scholle, P.A., 1993. Paleo-oceanographic Cycles and Events during the Late Cretaceous in the Western Interior Seaway of North America, in: Caldwell, W.G.E., Kauffman, E.G. (Eds.), Evolution of the Western Interior Basin. Geol. Ass. Canada, Spec. Pap., pp. 333-353.

Pratt, L.M., Threlkeld, C.N., 1984. Stratigraphic significance of 13C/12C ratios in midCretaceous rocks of the Western Interior, U.S.A, in: Stott, D.F., Glass, D.J. (Eds.), The Mesozoic of Middle North America. Canadian Society of Petroleum Geologist Memoir., pp. 305-312.

Premoli Silva, I., Sliter, W.V., 1999. Cretaceous paleoceanography: Evidence from planktonic foraminiferal evolution, in: Barrera, E., Johnson, C.A. (Eds.), Evolution of the Cretaceous Ocean-Climate System. Geological Society of America, pp. 301-328.

Price, G.D., Hart, M.B., 2002. Isotopic evidence for Early to mid-Cretaceous ocean temperature variability. Marine Micropaleontology 46, 45-58.

Sageman, B.B., 1985. High-resolution stratigraphy and paleobiology of the Hartland Shale Member; Analysis of an oxygen-deficient epicontinental sea, in: Pratt, L.M., Kauffman, E.G., Zelt, F.B. (Eds.), Fine-grained deposits of cyclic sedimentary processes. SEPM Field Trip Guidebook, 
pp. 110-121.

Sageman, B.B., Arthur, M.A., 1994. Early Turonian paleogeographic/paleobathymetric map, Western Interior, U.S, in: Caputo, M.V., Peterson, J.A., Franczyk, K.J. (Eds.), Mesozoic Systems of the Rocky Mountain Region, USA. SEPM, Rocky Mountain Section, pp. 457-470.

Sinninghe Damsté, J.S., van Bentum, E.C., Reichart, G.-J., Pross, J., Schouten, S., 2010. A $\mathrm{CO} 2$ decrease-driven cooling and increased latitudinal temperature gradient during the midCretaceous Oceanic Anoxic Event 2. Earth and Planetary Science Letters 293, 97-103.

Tsikos, H., Jenkyns, H.C., Walsworth-Bell, B., Petrizzo, M.R., Forster, A., Kolonic, S., Erba, E., Premoli Silva, I., Baas, M., Wagner, T., Sinninghe Damste, J.S., 2004. Carbon-isotope stratigraphy recorded by the Cenomanian-Turonian Oceanic Anoxic Event: correlation and implications based on three key localities. Journal of Geological Society 161, 711-719.

Ujiie, Y., De Garidel-Thoron, T., Watanabe, S., Wiebe, P., De Vargas, C., 2010. Coiling dimorphism within a genetic type of the planktonic foraminifer Globorotalia truncatulinoides. Marine Micropaleontology 77, 145-153.

Voigt, S., Gale, A.S., Voigt, T., 2006. Sea-level change, carbon cycling and palaeoclimate during the Late Cenomanian of northwest Europe; an integrated palaeoenvironmental analysis. Cretaceous Research 27, 836-858. 


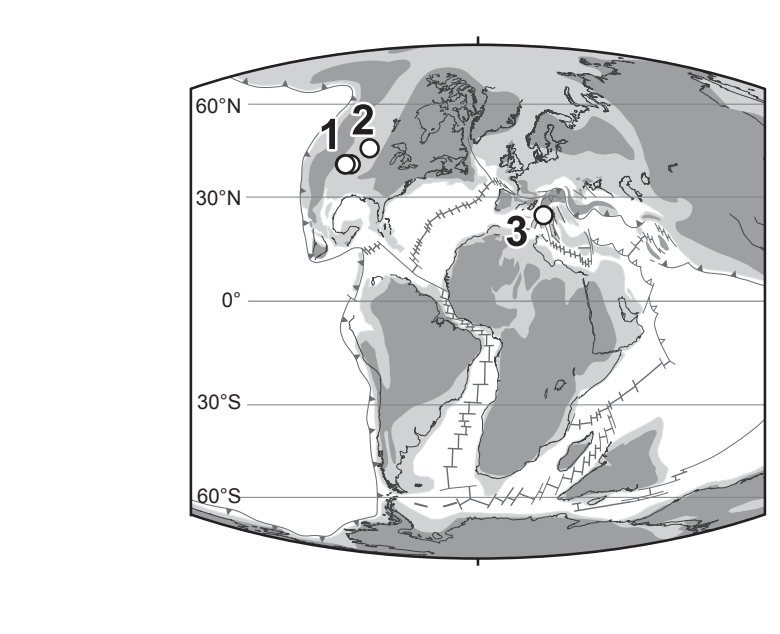

Figure_1

\section{Figure_1}
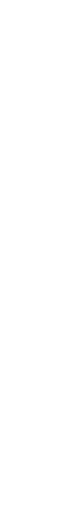

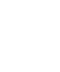

.


Figure_2
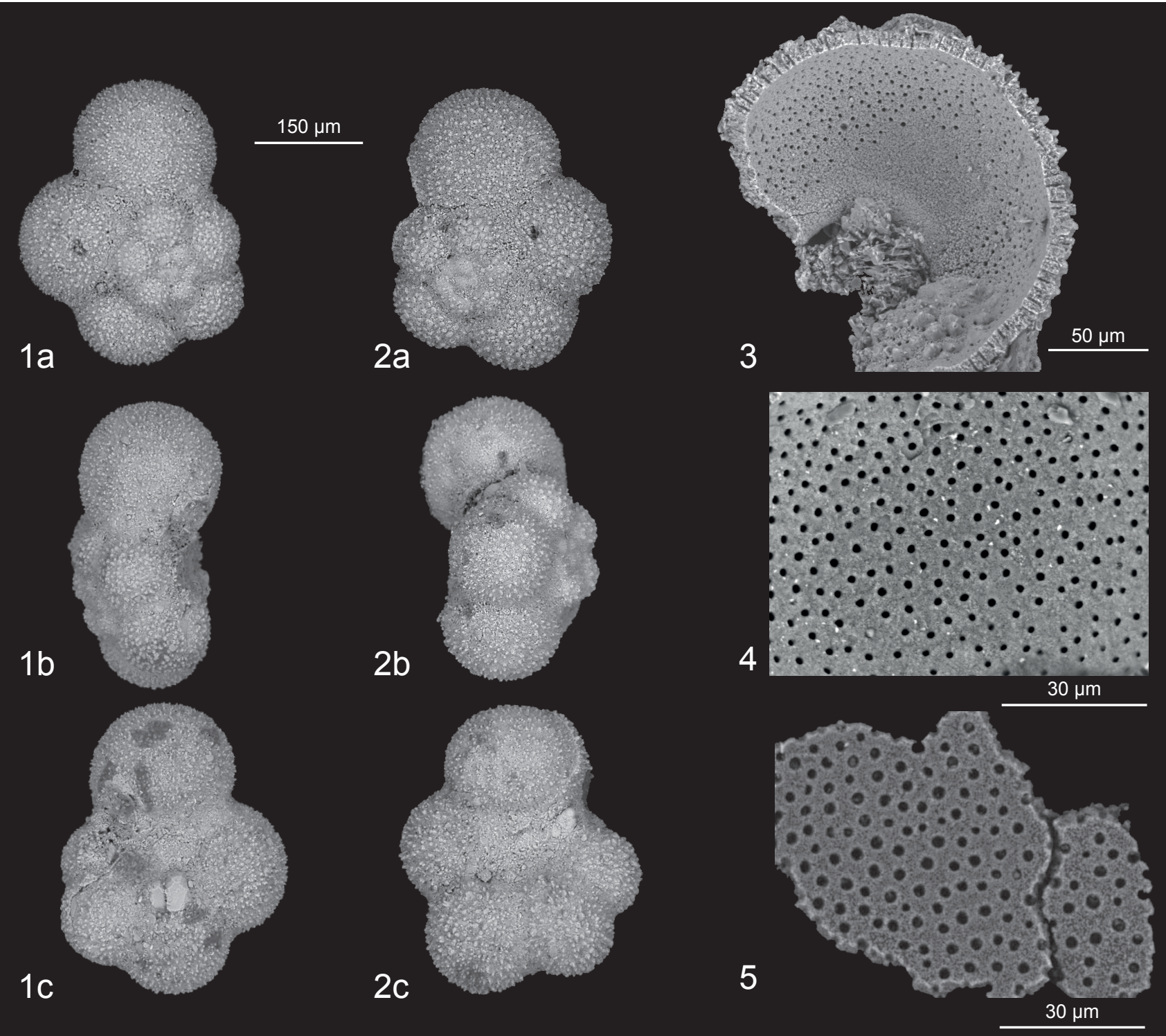
Figure_3

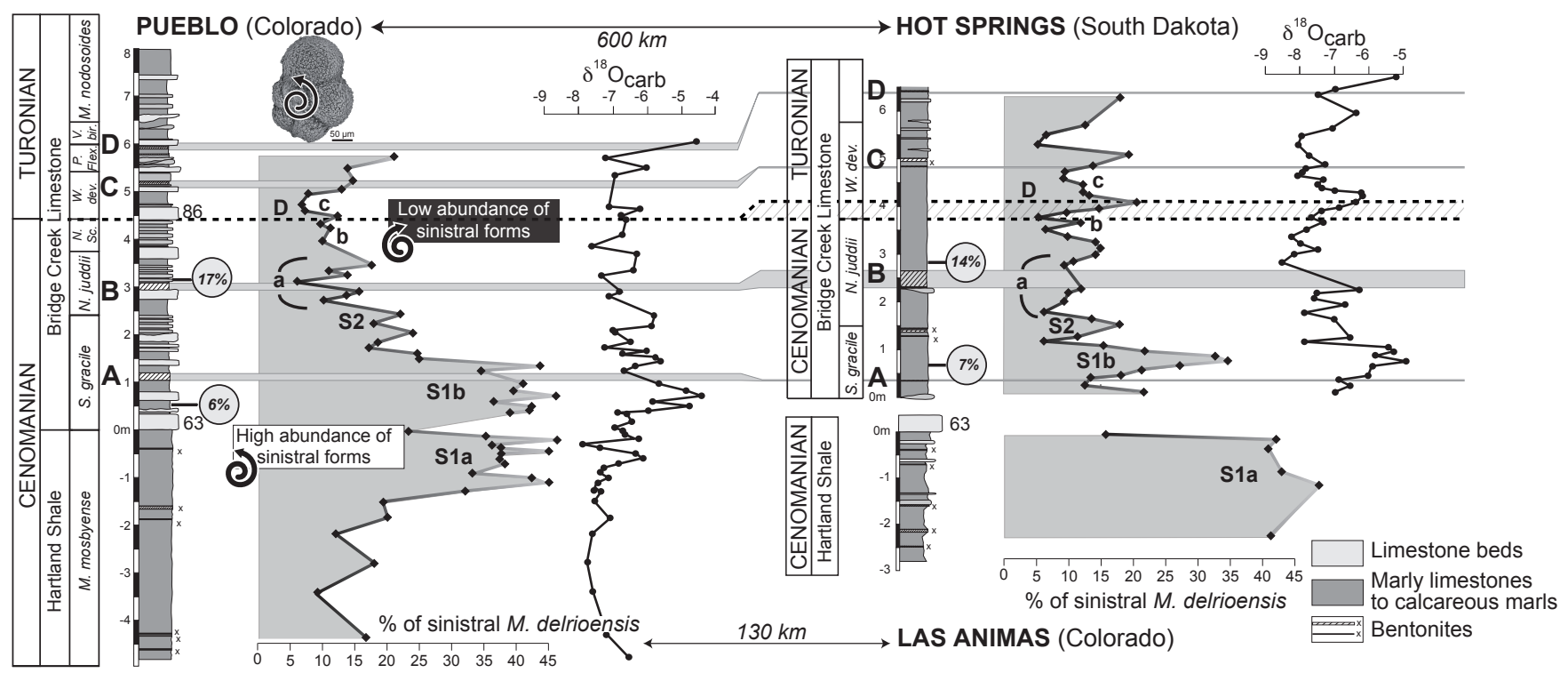




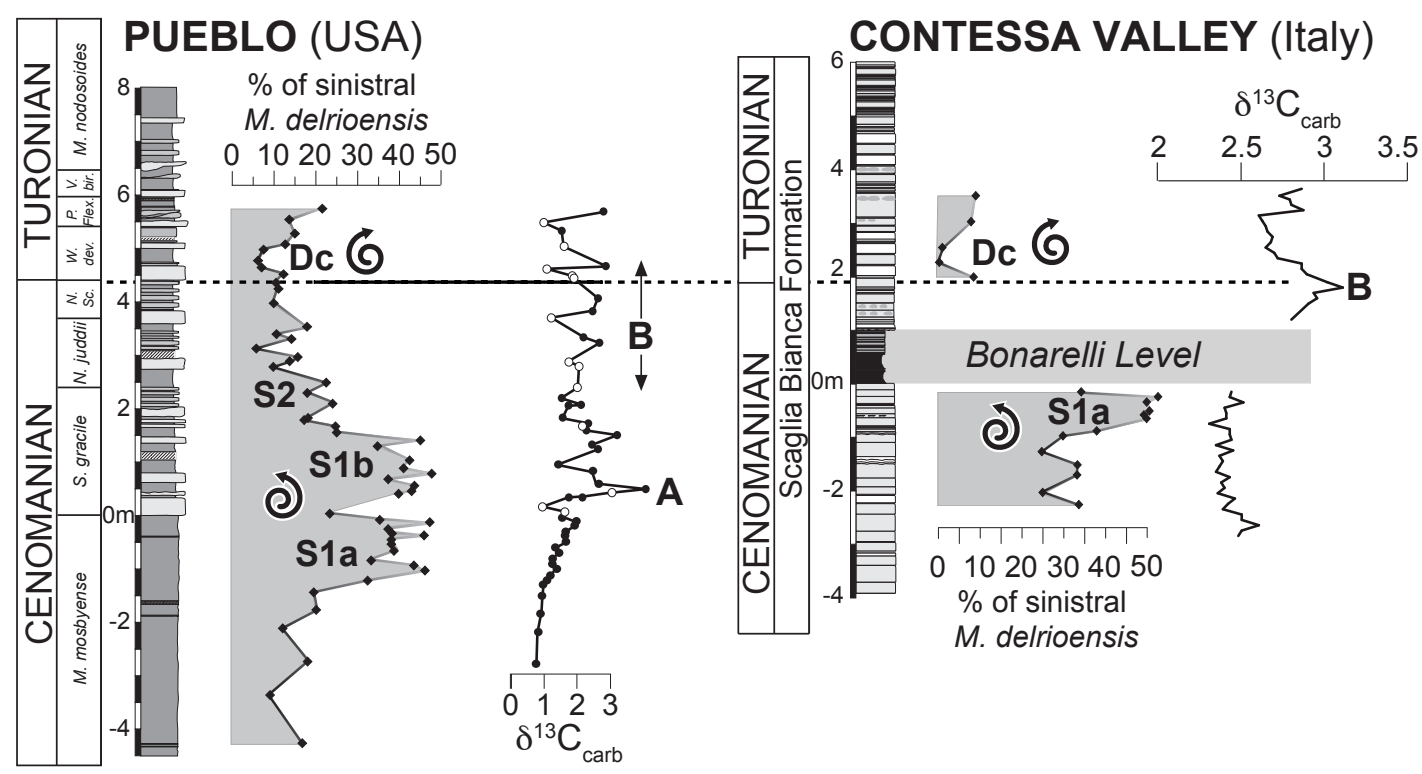


Figure_5
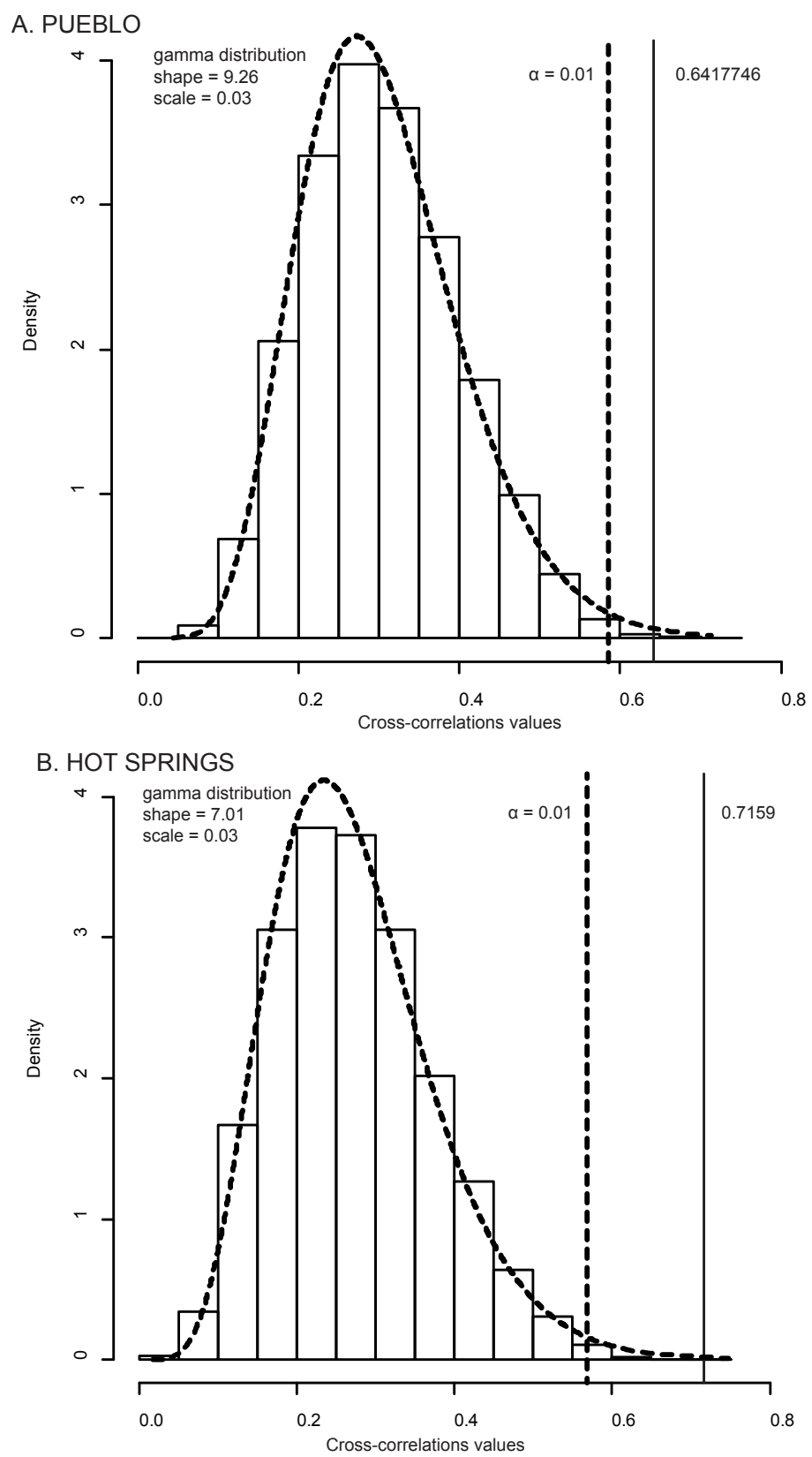


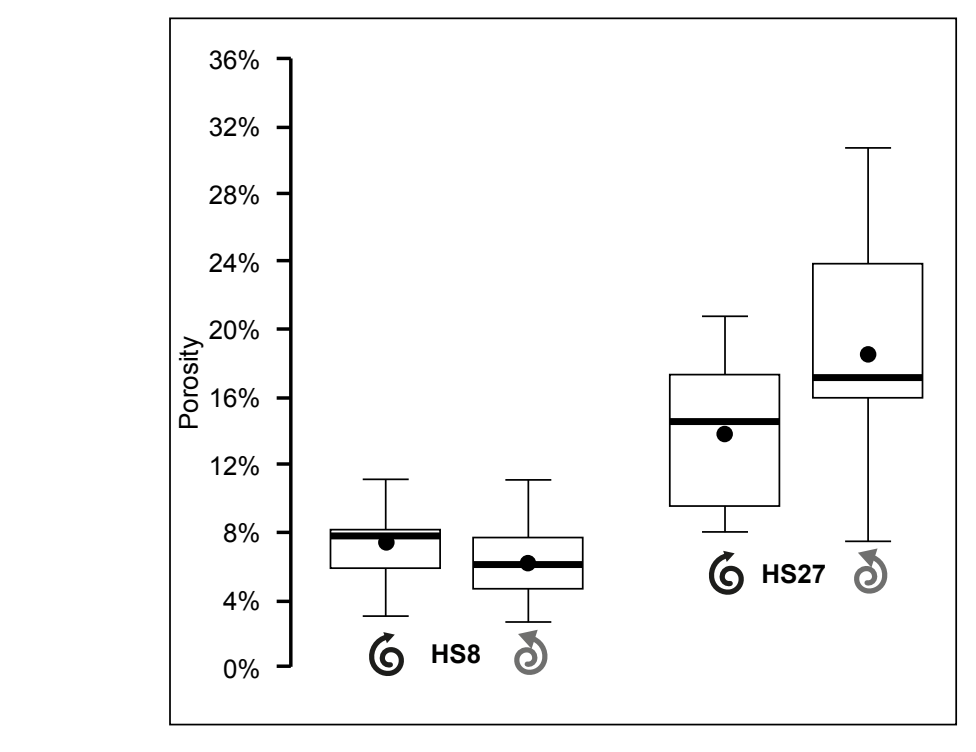

Figure_6

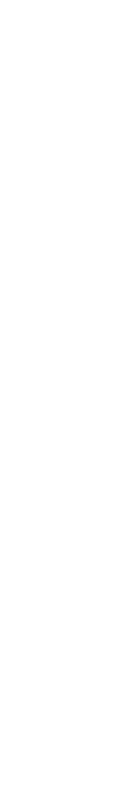

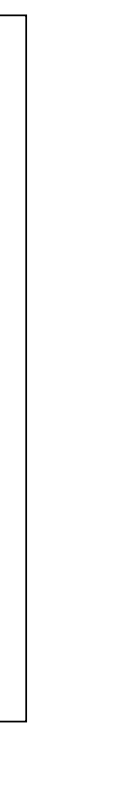

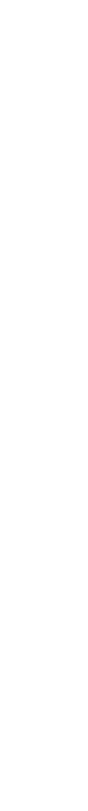


Figure_7
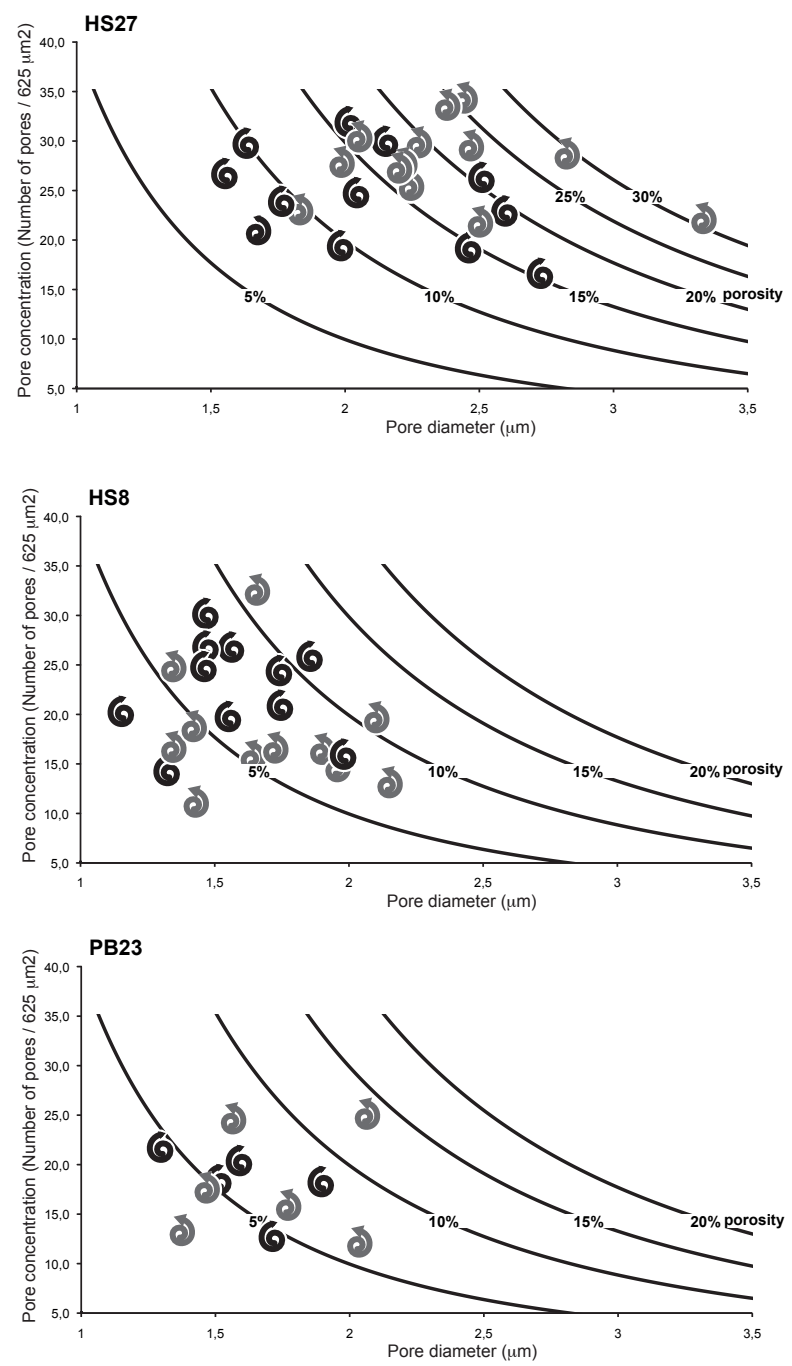
Figures captions

Figure 1. Cenomanian paleogeographic map (Vrielynck and Bouysse, 2003) with the location of Pueblo and Las Animas (USA, 1), Hot Springs (USA, 2) and the Contessa Valley (Italy, 3). Single-column fitting image

Figure 2. Scanning electron micrographs of M. delrioensis (Carsey, 1926) from Hot Springs. Number and height in brackets corresponds to sample number and the distance from the base of the $S$. gracile ammonite zone. 1. Dextral morphotype $(\mathrm{HS3}+0,26 \mathrm{~m}): 1 \mathrm{1a}$ spiral side, $1 \mathrm{~b}$. lateral view and 1c: umbilical side. 2. Sinistral morphotypes (HS3 +0,26 m) : 2a. spiral side, 2b. lateral view and 2c: umbilical side. 3. Scanning electron micrographs showing the variability of the inner porosity (HS8 +0,76); being non existent close to the foramen, porosity increases towards the opposite wall. 4. Inner porosity of the last chamber of a dextral $M$. delrioensis (HS8 +0,76) during S1b event. 5. Inner porosity of the last chamber of a dextral $M$. delrioensis (HS27 +2,65) during Da event. 2-column fitting image

Figure 3. $\delta^{18} \mathrm{O}_{\text {carb }}$ record compared with the changes in the percentage of sinistral $M$. delrioensis in the sections at Pueblo, Las Animas and Hot Springs. The main events in the $M$. delrioensis population are indicated as S1a and S1b and S2 (sinistral events) and Da, Db, Dc (the dextral events). These data are included in the high resolution chronostratigraphic scheme (Desmares et al., 2007) composed of the ammonite biozonation (Elder, 1987; Kennedy and Cobban, 1991) and the position of the bentonite marker beds A, B, C \& D. Inner test porosity averages are indicated in the light grey circles. The dashed lines indicate the position of the CTB. 2-column fitting image 
Figure 4. $\delta^{13} \mathrm{C}_{\text {carb }}$ records (Stoll and Schrag, 2000; Desmares et al., 2007) compared to the changes in the percentage of sinistral $M$. delrioensis in the sections at Pueblo and in the Contessa Valley. Isotopic $\delta^{13} \mathrm{C}$ events A: initial increase in values and first peak; B: second increase and plateau. 2-column fitting image

Figure 5. Histograms of cross-correlation values after the re-ordering procedure compared to cross-correlation of the raw variables (i.e. $\delta^{18} \mathrm{O}_{\text {carb }}$ and sinistral proportion) for both sections: A, Pueblo; B, Hot Springs. The continuous vertical line indicates the position of the crosscorrelation on the raw data. Dashed line shows the gamma distribution. The dashed vertical line indicates the 0.99 quantile of the gamma distribution. Single-column fitting image

Figure 6. Average inner porosities of the sinistral (grey left-coiled arrows) and the dextral (black right-coiled arrows) $M$. delrioensis and their standard deviations for the two samples HS8 and HS27 of the Hot Springs section. The thick black lines and the black dots respectively represent the medians and the main porosities. Single-column fitting image

Figure 7. Last chamber inner porosities of the dextral (black right-coiled arrows) and sinistral (grey left-coiled arrows) M. delrioensis during events S1b (HS8 and PB23) and Da (HS27). Single-column fitting image 
. dextral and sinistral morphotypes of $M$. delrioensis are common during the OAE2

. Several coiling direction changes among M. delrioensis are highlighted .$\delta^{18} \mathrm{O}$ and percentage of sinistral $M$. delrioensis variations are correlated . M. delrioensis coiling shift is a new proxy to estimate SST changes .M. delrioensis inner porosity is an additional SST index 